\title{
An Australian war correspondent in Ladysmith: The siege report of Donald Macdonald of the Melbourne Argus
}

\author{
IAN VAN DER WAAG \\ Military History Department, University of Stellenbosch (Military Academy)
}

Some one hundred years ago, South Africa was torn apart by the Second Anglo-Boer War (1899-1902). To mark this cataclysmic event, Covos-Day is publishing a series of books. The first is a facsimile of Donald Macdonald's enduring story of How we kept the flag flying through the siege of Ladysmith ${ }^{1}$ and this is followed by several other titles including another Ladysmith-siege diary: one written by George Maidment, a British army orderly. ${ }^{2}$ Such a publication programme is a monumental and laudable effort. It allows both reflections upon a calamitous episode in South African history and, as is the case of How we kept the flag flying, an opportunity for the collector to acquire old titles, long-out-of-print, at reasonable prices.

Donald Macdonald was born in Melbourne, Victoria on 6 June 1859. After a short career as a teacher, he joined the Corowa Free Press and, in 1881, the Melbourne Argus. A nature writer and cricket commentator, ${ }^{3}$ he arrived in South Africa on 21 October 1899, the day of the battle at Elandslaagte, as war correspondent to the Melbourne Argus. This book, How we kept the flag flying, was born from his experiences and frustrations whilst holed-up in Ladysmith throughout the 100-day siege, whilst the war raged and was reported on by journalists elsewhere.

The Second Anglo-Boer War was the last truly colonial war, the last interstate conflict of the nineteenth-century, the first of the twentieth and the first media war too. The press, as Thomas Pakenham has so eloquently pointed out, played a cardinal role in welding the people of the British Empire together and marshalling them behind the increasingly-unpopular war effort. The position in Australia was no different. There was, initially at least, no popular support and no popular imperialism. Much was made of the expressions of sympathy for the Uitlanders, such as that of May 1899 from the Mayor of Sydney, and a "mass meeting of Australians" in

Donald Macdonald, How we kept the flag flying: The story of the siege of Ladysmith (Covos Books: Roodepoort, 1999). 289 pages. Illustrated. Hard back. R140-00

A. Chalmers, Bombardment of Ladysmith anticipated; The Diary of a Siege (Covos-Day: Roodepoort, 1999); in addition to O. Coetzer, Fire in the sky: The Destruction of the Orange Free State 1899-1902 (1999); M. Flower-Smith and E. Yorke, Mafeking! The story of a siege (1999); D. Hall, Halt! Action Front! With Colonel Long at Colenso (1999); R.G. Hackett, South African War Books; An Illustrated Bibliography (1999); R. Milne, Anecdotes of the Anglo-Boer War (2000); and R. Milne (ed.), Battles of the Transvaal (2000).

A selection of Macdonald's nature writings was published in 1887 as Gum boughs and wattle bloom. After the war, a weekly nature column appeared in the Argus, which became "Notes for Boys" in 1909 and led to the Bush Boy's Book in 1911. This was enlarged in four more editions between 1927 and 1933. A nature book for children, At the end of the moonpath, appeared in 1922. He died in November 1932. 
Johannesburg on 27 May 1899. ${ }^{4}$ Recent research has shown that the gestures of support were "calculated and manufactured." The defeat of British arms during Black Week increased popular support; while the subsequent Australian operations around Colesberg were used "to hail the arrival of the Australian soldier." Here the Australian press, including Macdonald's paper, the Melbourne Argus, played no small part. ${ }^{5}$

Yet the love-hate relationship between the military - particularly the censor and the war correspondent had still to be ironed, if never quite sorted out. ${ }^{6}$ The problems were multi-faceted: they related to military security and the right to know; military incompetence and the freedom of the press; intricate military manoeuvre and ignorance of military affairs. In fact, as far as the war was concerned, Macdonald was imminently unqualified. He was a nature writer and cricket commentator, and he was to report on a war that all soon found would not be played by 'the rules'. It was a war that just wasn't cricket!

Macdonald appreciated his dilemma. South Africa was full of adventure and a nature lover's paradise but at the same time he would have to report on a phenomenon of which he knew nothing:

"In this book I have attempted no specialist's description of the siege and battles of Ladysmith, but have given just the everyday impressions and sensations of an observer to whom war, with all its thrilling incidents and vivid volour (sic), was a new and strange experience."

By his own admission, his knowledge of combat was limited to "the destruction of the Kelly gang of bushrangers, or a second-hand recital of the revolt of the Ballarat miners at Eureka." ${ }^{8} \mathrm{He}$ left the writing of "the complete military history of Ladysmith ... to the historian and the expert." ${ }^{.9}$ Setting Amery's Times History aside, which was initially a commercial venture and in any case sponsored by a newspaper, the first of these military histories commenced in August 1900 and four volumes appeared between 1906 and $1910 .{ }^{10}$ They, together with the single-volume Australian official history that appeared in $1911,{ }^{11}$ were official in every respect. The

See for example Transvaal Archives Depot (hereinafter TAD): archives of the British Agent (hereinafter BA) 21, Conyngham Greene - Milner, 30 May 1899 (f. 318A).

J. Grey, A Military History of Australia (Cambridge 1999), pp 52-61; and S. Clarke, "'Manufacturing Spontaneity'? The Role of the Commandants in the Colonial Offers of Troops to the South African War" in P. Dennis and J. Grey (eds.), The Boer War; Army, Nation, Empire (Canberra, 2000), pp 129-150.

6 L. Scholtz, 'The media and the military: Allies or adversaries?', Scientia Militaria 28(2) 1998, pp 236-251.

7 D. Macdonald, How We Kept The Flag Flying; The story of the Siege of Ladysmith (Roodepoort 1999), 'Author's Note' at front of book.

D. Macdonald, How We Kept The Flag Flying, p 7.

D. Macdonald, How We Kept The Flag Flying, Author's Note.

G.F.R. Henderson and F. Maurice, History of the War in South Africa, 1899-1902 (London 1906-1910).

P.L. Murray, Official records of the Australian military contingents to the war in South Africa, 1899-1902 (Melbourne 1911). This inconsistent assemblage of military minutiae by a junior officer who had served in South Africa is discussed by Craig Wilcox, 'The Australian official record' in C. Wilcox (ed.), Recording the South African War; Journalism and official history, 1899-1914 (London, 1999), pp 29-31. 
authors, were serving officers, Colonel G.F.R. Henderson (Roberts' invalided intelligence chief) and then Major General Sir Frederick Maurice; they had privileged access to classified official documents and to a variety of authoritative persons; and their products were commissioned and even written from within an official office. ${ }^{12}$ Furthermore, highlighting examples of good and bad generalship, good and bad strategy and tactics, and aimed at instruction for soldiers, they differed little in style and substance from the dour nineteenth-century products of the German general staff. ${ }^{13}$ Here official history and journalism laid down different yet complementary records of the war: the one utilitarian and often compromised by departmental interference and goodwill to fellow officers; the other readable and their writers, despite interference, at least seeking accuracy.

And here the value of How we kept the flag flying lies. Macdonald has provided a very readable account of one of the most memorable sieges of the century. $\mathrm{He}$ has recorded the events, some tedious some exuberant and exhilarating, in detail not found elsewhere. His personal account - "not so much a history of the siege as a story of the siege" - was "written while the events were fresh in the mind." Yet, judging from the intimate detail, Macdonald must have taken extensive notes during the siege and isolation of Ladysmith, and these must have been used as the basis for his 'story'.

Macdonald arrived in South Africa at a time when things were going relatively well for Britain. His ship was late arriving in Durban due to headwinds and " $[\mathrm{t}] \mathrm{hose}$ three lost days made a vast difference to some of us." ${ }^{14}$ He thus "had just missed" reporting on the battles of Talana and Elandslaagte, which had in any case "been described in detail by many eye-witnesses, more skilled in war and its detail than an Australian novice."15

Macdonald was a man of his time shackled by the contemporary prejudices for both the Boer and those people generically referred to as 'non-white'. Historians, even modern historians, have hinted that Australians learned racism and 'absorbed the local settlers' view' during their sojourn in South Africa during the war. ${ }^{16}$ Macdonald described the effects of the Battle of Rietfontein (30 Oct 1899) thus -

"It cleared the town of its human refuse - the mass of Hindoos and unattached Kaffirs who form such a very large share in the population of Natal, and will one day, I have no doubt, furnish it with its great social and political problem. The Asiatic was prominent in this railway rush. He carried with him as much of this world's goods as he could bundle together. He was wildly excited, and the more congested the crowd the more he chattered, and the faster he ran." (page 25).

Based upon a definition offered by Robin Higham thirty years ago. See the 'Introduction' to his Official histories: essays and bibliographies from around the world (Kansas, 1970), p 1.

3 K. Surridge, 'Official History' in C. Wilcox (ed.), Recording the South African War; Journalism and official history, pp 29-31.

D. Macdonald, How We Kept The Flag Flying, p 1.

D. Macdonald, How We Kept The Flag Flying, p 7.

See for example, C. Wilcox, 'Looking back on the South African War' in P. Dennis and J. Grey (eds.), The Boer War; Army, Nation, Empire (Canberra, 2000), p 7. 
At the time, Macdonald was but a brief nine days in South Africa. It is most unlikely that convictions underpinning such comments were laid down in such a short time. ${ }^{17}$ More plausibly, such colonials 'imported folk wisdom from the Australian bush' which did not differ markedly from any other part of the colonised world. ${ }^{18}$ While these sentiments are a crude statement of the racial politics in the British Empire as a whole; the passages in question provide a very vivid picture of the evacuation of Ladysmith as well as life in the isolated town.

The Boers were the focus of the second prejudice. They were backwoodsmen, far-removed from the coast and the British colonies, whose inland frontiers marked the furthest penetration of civilisation. The Boer, who according to The Times "steadily oppose[d] the advance of European civilization", ${ }^{19}$ had lapsed into savagery. Although Macdonald could see similarities between the Boers and "a camp of Australian shearers" and acknowledged their "matchless marksmanship", the Boer was not rated as an opponent:

"From the first their fire work was erratic, and when it came to the artillery duel there was but one in it. It was not the armament, but the man behind the gun. ${ }^{20}$

This gradually changed, but may have been, initially at least, a repetition of the unofficial line given the correspondents in the briefing sessions. The dehumanisation of the enemy is oft-used propaganda. By Christmas, Macdonald's sentiment had changed: "...the fact that they had already held so much of this colony of Natal for two months against an English force, which at one time would have been thought sufficient to carry the campaign to its climax, disposes for all time, I hope, the foolish impression that the Dutch are not fighting men."21

As Andrew Porter has pointed out, there were two forms of censorship at work: direct imposition by the military censor and 'indirectly as journalists developed their sense of censors' preferences. ${ }^{22}$ Yet the press censor, in Macdonald's case a Major Altham of the Royal Engineers, was "[t]he guide, philosopher, and perhaps one may say friend of war correspondents." Despite the censor's absolute mercilessness with his blue pencil, the correspondents were seldom offended and bore little ill will. Macdonald seemingly appreciated the need for military security as well as the fact that most of the time the journalists misunderstood the military situation. Many others compromised military security by sending unenciphered despatches through the gauntlet of the Boer snipers. Although precise military information could not be given, Altham always "accompanied the crucifixion of a cable despatch with such a pleasant and pointed fire of running comment that one could never be offended."

Similar statements are located on pages $40,58,61,80,114$ and elsewhere.

C. Wilcox, 'Looking back on the South African War' in P. Dennis and J. Grey (eds.), The Boer War, p 7.

R. Sibbald, The Boer War; The War Correspondents (Johannesburg, 1993), p 15.

D. Macdonald, How We Kept The Flag Flying, p 4.

D. Macdonald, How We Kept The Flag Flying, p 136-137.

A. Porter, 'Journalism' in C. Wilcox (ed.), Recording the South African War; Journalism and official history, $\mathrm{p} 1$. 
Indeed the intelligent journalist attempted to use such sessions for the acquisition or correction of information, chiefly to no avail: ${ }^{23}$

Correspondent (perhaps Macdonald). - "I shall be very glad, major, if you will amend them where incorrect."

Censor (Altham). - "No doubt; but then, you see, I'm not acting as correspondent for your paper."

Thus, due to military security, How we kept the flag flying and similar sources contain little on the planning and execution of military operations, and much of what was attempted is either wonderfully vague, comprised of half-truths or entirely incorrect. Macdonald wisely declared his dilemma and generally avoided tactical comment and operational speculation. There are exceptions. Shortly after his description of the isolation of Ladysmith, Macdonald explains why "Sir George White had left such commanding positions to the enemy..." ${ }^{24}$ His explanation is correct. Yet his usage of terminology - occupation in strength, mobility and defensive ring seems to suggest a military briefing to correspondents.

Conversely, the despatches and 'stories' of the correspondents, and here Macdonald is no exception, contain much on the aftermath of contacts. Of medical matters, both within the town, the convalescent camp and battlefield casualties. Macdonald's descriptions are vivid. The circumstances of the siege recorded in some detail, although oftentimes sensational. The siege reflected everything nasty about an old-fashioned war fought with modern technology. Mangled, shrapnel-torn bodies and the aftermath of battle, particularly, drew his morbid fascination. And so too the food rationing, increases in the number of typhoid cases, and the psychological impact of the artillery barrage: "On the first day ... people laughed ... On the second day there was rather less laughter ... On the third day there was an impressive silence ... On the fourth day men had a hunted look ... Most men were morose." 25 This was all very different from the boyish pursuits of nature trails and action on the cricket pitch.

The realities of modern warfare also hampered the work of the journalist. Macdonald bemoans the "loss in artistic effect." Here "the war artist had to presuppose, the war correspondent to imagine, much." There were no bright uniforms, no flags, no inspiring bands to lead the men into battle. No glitter or smoke or circumstance of any kind that could be observed and reported. In a nutshell, war had lost its "meretricious glamour" leaving little more than supposition on the part of the war artist and imagination to the war correspondent. ${ }^{26}$ At first, "a few rifle shots would have sent every correspondent to his saddle in anticipation of a fight; now we paid scarcely any attention to it." ${ }^{27}$

Comment on the Boers and Boer strategy flowed far more readily. This was not subject to military security, and information was gleaned from Boer prisoners and the official briefings. The Boers favoured a strategy of siege. It had worked well in the

D. Macdonald, How We Kept The Flag Flying, pp 43-44.

D. Macdonald, How We Kept The Flag Flying, p 30. These commanding positions were Pepworth's Hill and Umbulwana, "splendid position[s] for shelling both the camp and the town." 
past and held several advantages. The investment of key British garrisons would distract the British commander and the advance up the railway and into the republics over flat country would, at the very least, be delayed. He could even be defeated in one of colonies, preferably in the mountainous northern apex of Natal as in 1881, before entering the republics. One or more of the garrisons might be starved out and Boer casualties would be limited. The entire strategy revolved around the minimisation of the impact of the war upon the republican populations. Macdonald has the essence, gained no doubt from the British military authorities - they were in possession of the Boer campaign plan as early as June 1899 - and from Boer prisoners.

Macdonald makes reference to occasional interviews with Boer prisoners. Information was gleaned on Boer strategy, Smuts' idea of imploding of the Rand goldmines (on page 40, for example) and much else. Most of these prisoners did not keep diaries and would not go on to write memoirs. Hence the extra value of How we kept the flag flying lies in the capturing of information from such interviews that has not been laid down elsewhere. And here one must point out that the information drawn out by the military during an interrogation might differ considerably from that gleaned by the war correspondents in an interview. Unfortunately, Macdonald describes neither process. Yet, the Boer prisoners seemingly dispensed information readily.

The $2^{\text {nd }}$ Anglo-Boer War was undoubtedly a formative episode in the shaping of Australia and the first of several martial blocks in the building of Australian nationalism. It was the first war fought by Australians, the Commonwealth being formed in January 1901. In fact, "[w]ith a full appreciation of the patriotism and pride of race which has made Australasia a fighting unit of the British Empire, [Macdonald] dedicate[d] this book to [his] fellow-countrymen who took part in the South African Campaign." ${ }^{28}$ And strange as history would have it, Macdonald, arrived in South Africa aboard the S.S. Australasian. He referred patronisingly to "the volunteers of the loyal little colony of Natal...," ${ }^{29}$ minute geographically when drawn into comparison with Macdonald's new fatherland. Macdonald makes proud and frequent reference to the great Australian horses and good Australian medical doctors. Yet he refers to the imperial and colonial troops in South Africa as "an English force,",30 while the flag that they 'kept flying', and so prominently displayed on the cover of the book, was the Union Jack.

How we kept the flag flying is well presented within a sturdy yet attractive set of covers. It is printed on heavy paper and is stitch bound, and will surely still be in good condition at the time of the $2^{\text {nd }}$ Anglo-Boer War bicentennial. It is truly 'a classic in every sense' and possibly the best book published to mark the centennial of the Anglo-Boer War. It ranks historiographically with Sol Plaatje's Mafeking-siege diary, which too has seen a centenary edition. ${ }^{31}$

D. Macdonald, How We Kept The Flag Flying, Author's Note.

29 D. Macdonald, How We Kept The Flag Flying, p 2.

30 D. Macdonald, How We Kept The Flag Flying, p 136 and elsewhere.

31 J. Comaroff et al (eds.), The Mafeking Diary of Sol T. Plaatje (David Philip, Cape Town and James Curry, Oxford, 1999).
} 